\title{
Future-Proofing the Finance Function: An Empirical Approach
}

André de Waal

HPO Center, the Netherlands

Finance Function Research \& Development Center, the Netherlands

Eelco Bilstra

Finance Function Research \& Development Center, the Netherlands

\section{Jacques Bootsman}

Finance Function Research \& Development Center, the Netherlands

Julie Linthorst

HPO Center, the Netherlands

Nijenrode University, the Netherlands

\begin{abstract}
This paper investigates the question: How should a finance function deal with megatrends and disruptors in such a way that it can secure its sustainable performance? The existing literature contains little information on how to make the finance function 'future-ready' so that it can deal with its changing environment. Such changes consist mainly of threats (and some opportunities) caused by worldwide megatrends and disruptors. This gap in the current literature inhibits the ability of a finance function to prepare itself for the future. Based on a previous study of megatrends and disruptors, and using a framework for creating high-performing finance functions, this study determines the impact of megatrends and disruptors on organizations' finance functions. The resulting impact matrix and its robustness were evaluated by two groups of finance experts. The research resulted in the development of an impact matrix and a process -- called the Futurize! Diagnosis -- that the finance function can apply in order to make itself future-ready.
\end{abstract}

Keywords: Finance function, megatrends, disruptors, future-readiness, HPFF, high performance finance function, finance transformation, impact matrix 


\section{Introduction}

In the finance literature, and especially the professional and managerial finance literature, many studies can be found on the topic of 'the future of the finance function'. In this context, the term 'finance function' refers to all the financial processes of an organization. The professionals responsible for financial processes usually work in the finance department, but can also operate in other parts of the organization, for instance as business unit controllers (de Waal et al., 2019). Closer examination reveals that such studies mainly concern creating a world-class finance function (O'Connor et al., 2014, 2015) or a high performing finance function (CFO Research, 2014; de Waal et al., 2019). Very little literature can be found that discusses making the finance function 'future-ready' so that it can deal with changes in its environment, i.e. both inside the organization and externally. Such changes consist of threats caused by (worldwide) disruptors and megatrends, or opportunities provided by (mainly) megatrends. In this respect, the difference between 'the future of the finance function' and the 'future-ready finance function' is that the former discusses how the finance function should act and perform for its internal clients, i.e. being a business partner, technologically savvy, low-cost (see, for example, Farrar, 2019; Hoe, 2009), whereas the latter discusses how the finance function should deal with external circumstances, and especially challenges (caused by megatrends and disruptors) that originate externally (PwC, 2014).

The fact that there is limited literature on the future-readiness of finance functions represents a gap in not only the current literature but also in the ability of the finance function to prepare itself for the future. This is illustrated by the COVID pandemic of 2020 , which has shown that many organizations were not ready for the havoc it caused, resulting for many organizations in considerable negative consequences. There were also organizations which benefited from the pandemic (such as food producers, supermarkets and ICT companies). However, not all organizations are ready to take advantage of the changes in the environment (Kniffin et al., 2020; Koonin, 2020; Ribera, 2020). An organization and by extension all its functions should be more future-ready when dealing with threats or taking advantage of possibilities. In previous research we looked at how organizations as a whole can be made more future-ready (de Waal and Linthorst, 2020).

In this article we focus on how a specific organizational function can be made more future-ready: the finance function. We chose this function as we consider it as the most important supporting function in any organization, as it sits in the middle of the "organizational web" having connections and relations with all other functions in the organization. As such the finance function can have a pioneering role: when improving itself it can function as a role model for the other functions to follow suit (de Waal et al., 2019). To this end, we extended our previous study conducted into megatrends and disruptors (Linthorst and de Waal, 2020) to focus specifically on the finance function. Our goal is to identify how finance functions should adapt to megatrends and disruptors in such a way that they can become and remain high-performing. This is important because the finance function is one of the most important support functions in any organization (Nielsen and Kristensen, 2020; Wolf et al., 2015; Zoni and

International Journal of Management and Applied Research, 2021, Vol. 8, No. 2 
Merchant, 2007), as the organization relies on it to provide a high-quality service to internal and external customers.

Based on an extensive literature, Linthorst and de Waal (2020) identified fourteen megatrends and disruptors that are expected to have the most influence on organizations over the next decade. In this article, we match the fourteen megatrends and disruptors with the characteristics of the high-performance finance function (HPFF) created by de Waal et al. (2019) to specifically identify their effects on this function. For this, we apply the method used by de Waal and Linthorst (2020) and use a scientifically validated HPFF framework (de Waal et al., 2019) as the analytical model for our study. The HPFF framework makes it possible to evaluate the strengths and weaknesses of the finance function and it describes the characteristics of a finance function that operates at the highest level of quality. In addition, we discuss our research results and findings with experienced finance professionals in two round table discussions. In this way, we aim to answer the research question: How should a finance function deal with megatrends and disruptors in such a way that it can secure its sustainable performance? The performance of a finance function is measured by the satisfaction of its internal clients, its efficiency (the degree to which resources are used by the function in an expedient way), its effectiveness (the degree to which the finance function is successful in realizing its objectives), and its role in the organizational decision-making process (de Waal et al., 2019).

The remainder of this paper is structured as follows. The next section describes the fourteen megatrends and disruptors identified in prior research. This is followed by a section describing the HPFF framework. Subsequently, the megatrends and disruptors are matched with the factors of the HPFF framework. The next section describes the round table discussions conducted to verify the results of the matching and develops a process for making the finance function future-ready. The final section concludes the article and discusses limitations of the study and areas for further research.

\section{Megatrends and Disruptors}

In this section, the results of the previous research conducted by Linthorst and de Waal (2020) are summarized. In that study megatrends and disruptors were identified that will have an impact on the way organizations work in the future. Megatrends are large social, economic, political, and technological changes that are slow to form and, once in place, have an influence for a considerable amount of time (Naisbitt and Aburdene, 1990). Disruptors are defined by the Cambridge Dictionary as 'someone or something that prevents something, especially a system, process or event, from continuing as usual or as expected'. The main differences between megatrends and disruptors are the speed with which they appear and the effects they have. Megatrends are changes that take place gradually over a longer period of time, whereas disruptors are short-term, seemingly unexpected changes with high impact. In Linthorst and de Waal (2020), based on an extensive descriptive literature review, the following thirteen megatrends and one disruptor are distinguished:

International Journal of Management and Applied Research, 2021, Vol. 8, No. 2 
- Megatrend 1: Speed of technological advancement. Technological advancement is the collective term for the progress of technological and digital tools, such as automation, big data, and advanced analytics, which increase productivity and provide better access to information and ideas. Organizations have been automating their work for decades, but it is specifically the increasing speed of change in the technological field that makes technological advancement so disruptive.

- Megatrend 2: Flexible employment. Flexible employment refers to an increasing variety in working arrangements and work practices, including variation in working time/hours, working locations, amount and types of work contracts, and forms of employment contract. It is expected that traditional "nine-to-five jobs" will increasingly be replaced by mobile and on-demand employment, and that due to mobile technology and the Internet, teams of employees will not need to work in the same location anymore. There will also be a rise in 'fluid' positions and jobs where people have multiple roles within one organization or work as independent contractors. A gig-economy will emerge, which is a labor market in which temporary positions are common and organizations have contracts with independent workers for short-term engagements rather than long-term employment contracts.

- Megatrend 3: Skills mismatch. This refers to the expected gap between the skills of the existing/current workforce and the skills needed for jobs in the future. Learning new skills to adapt to the changing work environment is not a new phenomenon but, with the increasing speed of change, it is a challenge to prepare organizations, employees, and educational systems in time for these changes. In addition, it is becoming increasingly difficult to assess exactly what changes will occur and consequently what new skills are required.

- Megatrend 4: Sustainable employment. Sustainable employment refers to the extent to which workers are willing and able to remain working now and in the future. It is about offering work and working conditions that keep workers happy, healthy, and motivated. There is rising interest and concern around sustainable employment among management because in many (Western) countries there will be an imminent shortage of workers because of the aging working population. This is coupled with a growing awareness of sustainability issues in general among the population (and thus among the organization's clients).

- Megatrend 5: Continued globalization. Globalization is the process by which businesses or other organizations develop international influence or start operating on an international scale. Alternatively, it can refer to the growing interaction and integration among people, companies, and governments worldwide. Globalization is not new but nowadays it is seen as a similar force to the megatrends of 'technical advancement' and 'flexible employment'. In light of the COVID-19 pandemic, which caused global problems in production and logistics, there seems to be an upcoming trend of deglobalization for critical products, where countries want to start producing these products themselves instead of relying on imports.

- Megatrend 6: Changing workforce composition. Both the aging of the worldwide population and generational shifts are expected to cause changes in the future of work. Older employees not only represent an increasing proportion of the workplace, they are also working until an older age than previous generations. In addition to the aging of the world's population, the generational shifts from baby

International Journal of Management and Applied Research, 2021, Vol. 8, No. 2 
boomers (generation X, 1950s to 1970s) to millennials (generation Y, 1980s to 1990s), followed by generation Z (2000s, 2010s). In the future, generation A will cause major changes to the composition of the workforce, and by 2025 millennials (generation Y) will make up the majority of the workforce. As management still largely consists of boomers these "old-fashioned executives" will have to learn to deal with all these different generations.

- Megatrend 7: Increasing inequality. There is a growing concern about increasing wage and income inequality. Although employment rates have gone up globally, many categories of workers are not benefiting equally from this change, and their economic situation seems to be deteriorating. At particularly high risk of worsening economic conditions are low-skilled employees, employees with jobs that are likely to be replaced by automation, self-employed workers (gig-workers), and employees with a migrant background; in addition, the gender pay gap (which also creates differences in pay between workers) is not expected to disappear in the near future. Thus, there is an increasing need for social protection of vulnerable employees, with possible measures ranging from legal protection for individuals with flexible working arrangements to the introduction of a universal income.

- Megatrend 8: Environmental issues. This megatrend refers to changes in the world's climate, caused by human activity, and its consequences. Flooding, the rising sea level, extreme weather conditions, and natural disasters caused by climate change result in major infringements on daily life. These environmental issues are expected to have a huge negative impact on future economic growth because largescale investment must be made in reducing the ecological footprint of people and businesses, fostering sustainability, protecting the environment, and dealing with the expected migration of people from countries that are at risk of rising sea levels and flooding.

- Megatrend 9: Economic powershifts. Economic powershifts denote the shift in economic power from the developed West to the upcoming East. Asian countries, especially China and India, are becoming economically stronger, including globally, due, amongst other reasons, to the increasing consumption in neighboring countries. This has affected the competitive position of for-profit organizations in developed countries, making them more vulnerable to competitors but at the same time creating opportunities for growth in Asian countries.

- Megatrend 10: Urbanization. This refers to the worldwide population shift from rural to urban areas, as a consequence of which an increasing number of people are becoming permanently concentrated in relatively small areas (cities or metropolitan areas). This has an impact on organizations in rural as well as urban areas. In rural areas, there may be a drain in qualified workers leading to organizational bottlenecks, whereas urban areas are becoming overcrowded, leading to higher cost of living, increasing competition for jobs, and a more hectic or less balanced life, with negative consequences for health.

- Megatrend 11: Cross-border migration. Cross-border migration refers to employees moving to another country with the aim of finding (better) work. It occurs as a consequence of people being unable to find attractive work opportunities in their country of origin at the same time as other countries are unable to adequately fill their skills gaps. Cross-border migration changes the workforce composition and

International Journal of Management and Applied Research, 2021, Vol. 8, No. 2 
can create social problems. In addition, cross-border migrants are more vulnerable to get into bad economic conditions than native employees and they have a higher unemployment rate-especially those who have a non-Western background.

- Megatrend 12: Resource scarcity. This refers to the problem of increasing demand for resources such as water, food, energy, land, and minerals, which is causing scarcity in natural resources and inherent cost increases. Organizations increasingly need to address and reconsider their dependence on raw materials and resources. Finding new ways of working, innovation and the use of alternative resources will be key to their future survival. Even if organizations are not responding to such issues out of intrinsic motivation, public pressure and government intervention will force them to minimize their negative impacts on society and the environment.

- Megatrend 13: Individualism. This is the trend for people to seek to distinguish themselves from others, which is causing a shift from a collectivist society to a focus on the individual. People and organizations are increasingly expected to offer tailored and personalized products, services, and solutions. Organizations need to address the increasing demand for individual attention. Client and employee experiences have become key performance indicators that require close monitoring. Corporate approaches to training and mentoring are becoming more bespoke and tailored to individual career ambitions.

- Disruptor 1: Pandemics. The term pandemic refers to the worldwide spread of infectious diseases such as the 1918 Spanish flu, HIV/AIDS, and currently COVID19. Although pandemics did not appear as either a megatrend or disruptor in the existing literature on the future of work, the recent COVID-19 outbreak shows that pandemics do have a significant impact on societies and organizations globally, and thus organizations should pay greater attention to the influence of COVID-19. Consequences range from a shift to work from home, to economic crisis and also increased illness and mortality within the workforce.

\section{The High Performance Finance Function Framework}

The concept of the high-performance organization receives a lot of attention. To create and sustain such an organization all parts of the organization must contribute, and especially the finance function, whose relationships with every part of the organization mean that it can be regarded as the lynchpin in organizational performance. In the study of de Waal et al. (2019), the concept of the high-performance finance function (HPFF) was developed. Based on an extensive literature review, potential characteristics of the HPFF were identified. Using a questionnaire and statistical analysis, these potential characteristics were clustered into five HPFF factors that showed statistically significant positive relations with the finance function's performance. These factors are described below.

\section{Finance Function Improvement}

This HPFF factor mainly concerns the extent to which finance professionals are able to improve the finance function. The associated characteristics are as follows: improvement actions in the finance function are monitored and evaluated using performance indicators which will track progress and results of the improvements making quick adjustments possible; the implementation of improvements is tackled in

International Journal of Management and Applied Research, 2021, Vol. 8, No. 2 
a structured manner; finance personnel are able to spend sufficient time on making their activities more effective and efficient; and the implementation of improvements in the finance function is actively encouraged. In addition, processes are carried out as uniformly as possible and by one team (sometimes organized in a shared service center) so that process expertise is developed and maintained. Finally there is a characteristic that allows line managers to become less dependent on the finance function for their finance-related needs while at the same time giving the finance function more time to devote to more complex tasks: finance self-service systems. 'Self-service' means that line managers can prepare their own reports without the intervention of people from the finance function.

\section{IT Focus}

This HPFF factor emphasizes the importance of automation and digitization for strengthening the finance function. Its characteristics are as follows: the finance function has a sufficient annual budget to accelerate the automation and digitization of the function; and automation and digitization are given high priority. Also important for this factor is finance personnel's knowledge of the new IT applications that could be applied in the finance function and in the organization as a whole: the finance function is aware of the latest applications and the possibilities that IT programs offer; and the finance function is able to implement the most recent IT applications. Finally, this factor includes characteristics that reflect the results of the focus on IT: all routine finance processes are fully automated; and the finance function spends less and less time on these routine activities.

\section{Development of Finance Professionals}

The focus here is on the continuous development of finance personnel which is taken seriously by management and the financials themselves, as is evident from the characteristics of this third factor: in the past year, finance personnel have undertaken sufficient technical training to be able to excel in their position; in the past year, finance personnel have undertaken sufficient personal development training to be able to excel in their position; and all finance personnel have a personal development plan.

\section{Role Clarity}

This HPFF factor concerns the clarity of the different roles that exist in the finance function. After all, finance roles vary and different requirements must be assigned to these different roles in the finance function. In addition, these roles should be known in the organization so people know to whom to turn with specific questions. The corresponding characteristics for this factor are: in the finance function there is a clear description of the technical requirements for each finance role; in the finance function there is a clear description of the desired behavior for each finance role; and in the finance function specific development programs have been established for each finance role.

\section{Strategic Role}

This HPFF factor relates to the way in which the organization's leaders, and especially those in operations, view and interact with the finance function. The characteristics are: the finance function is a fully-fledged discussion partner at the strategic level; the finance function has an important say in any decision of strategic importance; the

International Journal of Management and Applied Research, 2021, Vol. 8, No. 2 
finance function is spontaneously asked for advice by other departments that need to make important decisions; the finance function is actively involved in all major projects and processes of the organization; and the finance function is increasingly adding value to the organization's operations. This factor also puts a great deal of emphasis on cooperation between the finance function and operations: the finance function actively seeks opportunities for cooperation with operations; and the finance function regularly examines possibilities for adding value to operations in collaboration with line managers. An important part of fulfilling the strategic role is facilitating forecasting and foresight: the finance function proactively adjusts forecasts based on important events; and the version of the forecast most recently adjusted by the finance function is always given priority in important management team decisions.

\section{Matching The Megatrends/Disruptor With The HPFF Factors}

To evaluate how the megatrends and disruptor impact the HPFF framework, we construct an impact matrix in which we combine the megatrends and disruptor with the factors and characteristics of the HPFF framework. For each of the thirteen megatrends and one disruptor, we analyzed whether and how they could impact each of the five HPFF factors and its underlying characteristics. The lead author made the first draft of the impact matrix because he had prior experience of making such a matrix (de Waal and Linthorst, 2020). Subsequently, the other authors reviewed the impact matrix and made changes where they saw fit, each building on the review work of the previous person, until all authors had given their input. The lead author was then able to finalize the impact matrix. This approach resembles the strategic foresight method: the futurist begins with the megatrend or disruptor and thinks of possible direct consequences of that megatrend/disruptor (Paliokaite et al., 2014). Table I summarizes the results of the matching, detailed matching results can be obtained on request from the authors. Table I shows that the HPFF factors can be affected in both positive and negative ways by the megatrends, but are mostly negatively affected by the disruptor. In other words, some megatrends create opportunities, whereas other megatrends and the disruptor create threats to finance functions $(\mathrm{FF})$.

International Journal of Management and Applied Research, 2021, Vol. 8, No. 2 
Table 1: Summary of the consequences of the megatrends and disruptor on the HPFF factors

\begin{tabular}{|c|c|c|c|c|c|}
\hline $\begin{array}{r}\text { Megatrends/ } \\
\text { disruptor }\end{array}$ & $\begin{array}{c}\text { Finance function } \\
\text { improvement }\end{array}$ & IT focus & $\begin{array}{c}\text { Personnel } \\
\text { development }\end{array}$ & Role clarity & Strategic role \\
\hline $\begin{array}{l}\text { M1. } \\
\text { Speed of } \\
\text { technological } \\
\text { advancement }\end{array}$ & $\begin{array}{l}\text { New technologies } \\
\text { enable many } \\
\text { improvements in } \\
\text { the FF }\end{array}$ & $\begin{array}{l}\text { New technologies require } \\
\text { continuous updating of } \\
\text { knowledge in the FF } \\
\text { - New technologies make it } \\
\text { possible to automate } \\
\text { routine processes so that } \\
\text { the FF has more time for } \\
\text { other tasks }\end{array}$ & $\begin{array}{l}\text { New technologies } \\
\text { require continuous } \\
\text { updating of knowledge } \\
\text { by finance personnel, } \\
\text { who should be given } \\
\text { sufficient time for this }\end{array}$ & $\begin{array}{l}\text { New technologies } \\
\text { require new descriptions } \\
\text { of current roles and also } \\
\text { the creation of new roles }\end{array}$ & $\begin{array}{l}\text { The FF must contribute } \\
\text { knowledge about the } \\
\text { possibilities of new } \\
\text { technologies during } \\
\text { strategic discussions and } \\
\text { important projects and } \\
\text { processes }\end{array}$ \\
\hline $\begin{array}{l}\text { M2. } \\
\text { Flexible } \\
\text { employment }\end{array}$ & $\begin{array}{l}\text { The increasing } \\
\text { number of flexible } \\
\text { employees/worker } \\
\text { s makes it more } \\
\text { difficult to structure } \\
\text { and work on } \\
\text { improvements with } \\
\text { sufficient speed }\end{array}$ & $\begin{array}{l}\text { - It is becoming more } \\
\text { difficult to develop IT } \\
\text { expertise and keep this } \\
\text { knowledge in the } \\
\text { company with employees } \\
\text { who only work part-time or } \\
\text { on an on-call basis } \\
\text { - Routine financial } \\
\text { processes must be fully } \\
\text { automated so that flexible } \\
\text { workers can mainly be } \\
\text { used for specialist tasks }\end{array}$ & $\begin{array}{l}\text { The FF is less able to } \\
\text { influence the } \\
\text { development of } \\
\text { flexible workers } \\
\text { - The FF should pay } \\
\text { more attention to the } \\
\text { development of the } \\
\text { skills needed for } \\
\text { remote working }\end{array}$ & $\begin{array}{l}\text { Flexible workers bring } \\
\text { in specialist } \\
\text { knowledge and act as } \\
\text { innovators / drivers } \\
\text { for change } \\
\text { - The FF will have to } \\
\text { invest in the } \\
\text { development of } \\
\text { flexible workers }\end{array}$ & $\begin{array}{l}\text { Flexible workers may not } \\
\text { work at the FF for long } \\
\text { enough to become } \\
\text { strategic partners and to } \\
\text { enter into partnerships } \\
\text { with other parts of the } \\
\text { organization }\end{array}$ \\
\hline $\begin{array}{l}\text { M3. } \\
\text { Skills mismatch }\end{array}$ & $\begin{array}{l}\text { The FF must train } \\
\text { employees to have } \\
\text { the skills to work } \\
\text { on improvements } \\
\text { in a structured way }\end{array}$ & $\begin{array}{l}\text { The FF must use a (large) } \\
\text { part of its budget to increase } \\
\text { the knowledge and skill levels } \\
\text { of employees }\end{array}$ & $\begin{array}{l}\text { The FF must give } \\
\text { employees time to work } \\
\text { on their knowledge and } \\
\text { skills }\end{array}$ & $\begin{array}{l}\text { Role descriptions and } \\
\text { development programs } \\
\text { must ensure to close the } \\
\text { gaps between desired } \\
\text { and available skills }\end{array}$ & $\begin{array}{l}\text { The FF must ensure that } \\
\text { the strategic partnership } \\
\text { skills of employees are } \\
\text { developed to the desired } \\
\text { level }\end{array}$ \\
\hline $\begin{array}{l}\text { M4. } \\
\text { Sustainable } \\
\text { employment }\end{array}$ & $\begin{array}{l}\text { Actions must be } \\
\text { taken to improve } \\
\text { working conditions } \\
\text { within the FF }\end{array}$ & $\begin{array}{l}\text { The FF's budget should be } \\
\text { used for automation that } \\
\text { promotes sustainable } \\
\text { employment }\end{array}$ & $\begin{array}{l}\text { The development of } \\
\text { employees must be } \\
\text { given importance so that } \\
\text { they feel confident and } \\
\text { good about themselves }\end{array}$ & $\begin{array}{l}\text { Development programs } \\
\text { must take into account } \\
\text { the promotion of } \\
\text { sustainable employment } \\
\text { ('one size does not fit } \\
\text { all') }\end{array}$ & \\
\hline
\end{tabular}


Future-Proofing the Finance Function: An Empirical Approach

\begin{tabular}{|c|c|c|c|c|c|}
\hline $\begin{array}{r}\text { Megatrends/ } \\
\text { disruptor }\end{array}$ & $\begin{array}{l}\text { Finance function } \\
\text { improvement }\end{array}$ & IT focus & $\begin{array}{c}\text { Personnel } \\
\text { development }\end{array}$ & Role clarity & Strategic role \\
\hline $\begin{array}{l}\text { M5. } \\
\text { Continued } \\
\text { globalization }\end{array}$ & $\begin{array}{l}\text { A globally } \\
\text { operating } \\
\text { organization must } \\
\text { find a good } \\
\text { balance between } \\
\text { standardization } \\
\text { and customization } \\
\text { of its financial } \\
\text { processes }\end{array}$ & $\begin{array}{l}\text { The FF must be able to } \\
\text { implement ICT applications in } \\
\text { many different (regional) } \\
\text { settings. }\end{array}$ & & $\begin{array}{l}\text { Role descriptions and } \\
\text { development programs } \\
\text { must take into account } \\
\text { local circumstances }\end{array}$ & $\begin{array}{l}\text { The FF will have to } \\
\text { develop an international } \\
\text { outlook to be a good } \\
\text { discussion partner in a } \\
\text { globally operating } \\
\text { organization, and at the } \\
\text { same time must have } \\
\text { knowledge of local } \\
\text { conditions }\end{array}$ \\
\hline $\begin{array}{l}\text { M6. } \\
\text { Changing } \\
\text { workforce } \\
\text { composition }\end{array}$ & $\begin{array}{l}\text { The increase of } \\
\text { millennials in the } \\
\text { workforce will } \\
\text { accelerate the use } \\
\text { of digital } \\
\text { applications }\end{array}$ & $\begin{array}{l}\text { The increase of millennials in } \\
\text { the workforce leads to an } \\
\text { increase in available IT } \\
\text { knowledge }\end{array}$ & $\begin{array}{l}\text { Training courses will } \\
\text { have to be more } \\
\text { precisely tailored and } \\
\text { differentiated for the } \\
\text { different generations } \\
\text { working in the FF } \\
\end{array}$ & & \\
\hline $\begin{array}{l}\text { M7. } \\
\text { Increasing } \\
\text { inequality }\end{array}$ & & & $\begin{array}{l}\text { The FF's management } \\
\text { must ensure that all } \\
\text { personnel have equal } \\
\text { development } \\
\text { opportunities }\end{array}$ & & $\begin{array}{l}\text { The FF must be aware of } \\
\text { growing inequality and its } \\
\text { consequences for the } \\
\text { organization, and of the } \\
\text { financial and social } \\
\text { impacts of the } \\
\text { organization's actions on } \\
\text { inequality }\end{array}$ \\
\hline $\begin{array}{l}\text { M8. } \\
\text { Environmental } \\
\text { issues }\end{array}$ & $\begin{array}{l}\text { There will be an } \\
\text { explicit need to } \\
\text { make } \\
\text { improvements that } \\
\text { better prepare the } \\
\text { FF (and the } \\
\text { organization) for } \\
\text { the consequences } \\
\text { of environmental } \\
\text { issues }\end{array}$ & $\begin{array}{l}\text { Standardization is given high } \\
\text { priority because it makes the } \\
\text { FF (and the organization) } \\
\text { less vulnerable to the } \\
\text { consequences of } \\
\text { environmental issues }\end{array}$ & & & $\begin{array}{l}\text { The FF must have } \\
\text { knowledge of } \\
\text { environmental issues } \\
\text { and their } \\
\text { consequences and } \\
\text { risks for the } \\
\text { organization, and of } \\
\text { the financial and social } \\
\text { effects of the } \\
\text { organization's } \\
\text { activities }\end{array}$ \\
\hline
\end{tabular}

International Journal of Management and Applied Research, 2021, Vol. 8, No. 2 
Future-Proofing the Finance Function: An Empirical Approach

\begin{tabular}{|c|c|c|c|c|c|}
\hline $\begin{array}{r}\text { Megatrends/ } \\
\text { disruptor }\end{array}$ & $\begin{array}{c}\text { Finance function } \\
\text { improvement }\end{array}$ & IT focus & $\begin{array}{c}\text { Personnel } \\
\text { development }\end{array}$ & Role clarity & Strategic role \\
\hline & & & & & $\begin{array}{l}\text { Financial forecasts } \\
\text { (short and long term) } \\
\text { must explicitly take } \\
\text { into account } \\
\text { developments and } \\
\text { consequences of } \\
\text { environmental issues }\end{array}$ \\
\hline $\begin{array}{l}\text { M9. } \\
\text { Economic } \\
\text { powershifts }\end{array}$ & $\begin{array}{l}\text { Shifts in economic } \\
\text { power can } \\
\text { encourage the } \\
\text { FF's management } \\
\text { to make quicker } \\
\text { decisions on } \\
\text { relocating the FF's } \\
\text { processes }\end{array}$ & $\begin{array}{l}\text { The FF must be able to } \\
\text { implement IT applications in } \\
\text { different international settings }\end{array}$ & $\begin{array}{l}\text { Training courses must } \\
\text { take into account the } \\
\text { new markets and } \\
\text { stakeholders that the FF } \\
\text { will have to deal with }\end{array}$ & & $\begin{array}{l}\text { - The FF must have } \\
\text { knowledge of the } \\
\text { consequences, risks, } \\
\text { and opportunities for } \\
\text { the organization of } \\
\text { economic power } \\
\text { shifts } \\
\text { - Financial forecasts } \\
\text { (short and long term) } \\
\text { must explicitly take } \\
\text { into account } \\
\text { economic power } \\
\text { shifts }\end{array}$ \\
\hline $\begin{array}{l}\text { M10. } \\
\text { Urbanization }\end{array}$ & & & & & $\begin{array}{l}\text { The FF must have } \\
\text { knowledge of the } \\
\text { consequences and } \\
\text { risks of urbanization } \\
\text { for the organization } \\
\text { - Financial forecasts } \\
\text { (short and long term) } \\
\text { must explicitly take } \\
\text { into account the } \\
\text { consequences of } \\
\text { urbanization for the } \\
\text { organization }\end{array}$ \\
\hline
\end{tabular}

International Journal of Management and Applied Research, 2021, Vol. 8, No. 2 
Future-Proofing the Finance Function: An Empirical Approach

\begin{tabular}{|c|c|c|c|c|c|}
\hline $\begin{array}{l}\text { Megatrends/ } \\
\text { disruptor }\end{array}$ & $\begin{array}{l}\text { Finance function } \\
\text { improvement }\end{array}$ & IT focus & $\begin{array}{c}\text { Personnel } \\
\text { development }\end{array}$ & Role clarity & Strategic role \\
\hline $\begin{array}{l}\text { M11. } \\
\text { Cross-border } \\
\text { migration }\end{array}$ & & & $\begin{array}{l}\text { Personal development } \\
\text { plans must explicitly take } \\
\text { into account the } \\
\text { migration background of } \\
\text { employees }\end{array}$ & $\begin{array}{l}\text { The FF may have to } \\
\text { provide specific training } \\
\text { to new employees with a } \\
\text { migrant background on } \\
\text { the desired behaviors in } \\
\text { the organization }\end{array}$ & $\begin{array}{l}\text { The FF must have } \\
\text { knowledge of the } \\
\text { consequences of } \\
\text { migration for the } \\
\text { organization } \\
\text { - Financial forecasts } \\
\text { (short and long term) } \\
\text { must explicitly take } \\
\text { into account the } \\
\text { consequences of } \\
\text { migration for the } \\
\text { organization }\end{array}$ \\
\hline $\begin{array}{l}\text { M12. } \\
\text { Resource } \\
\text { scarcity }\end{array}$ & $\begin{array}{l}\text { Improvement } \\
\text { actions must } \\
\text { explicitly take into } \\
\text { account the } \\
\text { scarcity of } \\
\text { particular } \\
\text { resources }\end{array}$ & $\begin{array}{l}\text { Digitization must be given } \\
\text { high priority where it is able to } \\
\text { ensure that the organization } \\
\text { will use lower amounts of } \\
\text { scarce resources }\end{array}$ & & & $\begin{array}{l}\text { The FF must be } \\
\text { aware of the } \\
\text { consequences and } \\
\text { risks of resource } \\
\text { scarcity for the } \\
\text { organization } \\
\text { - The FF must acquire } \\
\text { knowledge about } \\
\text { alternative scarce } \\
\text { resources in order to } \\
\text { advise the operation } \\
\text { - Financial forecasts } \\
\text { (short and long term) } \\
\text { will have to explicitly } \\
\text { take into account the } \\
\text { consequences for the } \\
\text { organization of } \\
\text { resource scarcity }\end{array}$ \\
\hline
\end{tabular}

International Journal of Management and Applied Research, 2021, Vol. 8, No. 2 
Future-Proofing the Finance Function: An Empirical Approach

\begin{tabular}{|c|c|c|c|c|c|}
\hline $\begin{array}{r}\text { Megatrends/ } \\
\text { disruptor }\end{array}$ & $\begin{array}{c}\text { Finance function } \\
\text { improvement }\end{array}$ & IT focus & $\begin{array}{c}\text { Personnel } \\
\text { development }\end{array}$ & Role clarity & Strategic role \\
\hline $\begin{array}{l}\text { M13. } \\
\text { Individualism }\end{array}$ & & & $\begin{array}{l}\text { The FF will increasingly } \\
\text { have to take the wishes } \\
\text { of individual employees } \\
\text { into account and tailor } \\
\text { training programs to } \\
\text { them }\end{array}$ & & $\begin{array}{l}\text { The FF must have } \\
\text { knowledge of the } \\
\text { consequences, risks, } \\
\text { and opportunities of } \\
\text { individualism for the } \\
\text { organization }\end{array}$ \\
\hline D1. Pandemics & $\begin{array}{l}\text { Improvements } \\
\text { must primarily be } \\
\text { aimed at better } \\
\text { protecting the FF } \\
\text { against } \\
\text { pandemics, or } \\
\text { better dealing with } \\
\text { the consequences } \\
\text { thereof }\end{array}$ & $\begin{array}{l}\text { - Standardization and } \\
\text { centralization must be } \\
\text { given high priority in order } \\
\text { to make the FF more } \\
\text { resilient to increased sick } \\
\text { leave during a pandemic } \\
\text { - Automation should make } \\
\text { remote working / working } \\
\text { from home possible and } \\
\text { efficient }\end{array}$ & & & $\begin{array}{l}\text { - The FF must have } \\
\text { knowledge of the } \\
\text { consequences and } \\
\text { risks of pandemics for } \\
\text { the organization } \\
\text { - Financial forecasts } \\
\text { (short and long term) } \\
\text { must explicitly take } \\
\text { into account the } \\
\text { consequences of } \\
\text { pandemics for the } \\
\text { organization }\end{array}$ \\
\hline
\end{tabular}




\section{Analysis}

In order to evaluate the robustness of the impact matrix, we organized two round table discussions with experienced finance professionals. The reasons for using a group of experts are that experts bring knowledge, authority, and insight to a topic (Gutierrez, 1989) and that a group of experts is better than one expert (Gupta and Clarke, 1996; Hill, 1982). Groups of experts are often brought together in round table discussions to exchange opinions, knowledge, views, and ideas (Crabtree and Miller, 1992; Merriam, 1998) in a time-efficient and effective manner, and such discussions are used in a wide variety of research fields (see, for example, Haq et al., 2017; OECD, 2007; Saludadez and Garcia, 2001; Singer et al., 2019; Smith et al., 2010). The finance experts used in the present study originated from our networks and were selected based on the length of experience working in finance functions and their organizational position and role, which were required to provide them with involvement in strategic developments of their organization and finance function. We used a limited number of professionals in each round table so that a 'real' discussion could take place in which everybody had ample time to share their opinions and experience. Thus, during each roundtable seven different professionals participated, who had roles such as CFO, finance director, internal audit manager, finance advisor or head of planning \& control. Each participant had at least ten years' experience in finance functions of Dutch middle-sized and large companies. The reason for conducting two round tables was to give the opportunity for participants in the second round table to build on the results of the first round table, thus raising the overall quality of the discussion results.

To evaluate the robustness of the impact matrix, we asked the round table participants the following discussion question: "Given the influences of the thirteen megatrends and one disruptor on the finance function, how are you going to approach making your finance function future-ready, what are you going to do in practice?" We intended that the answers to this question would yield a generalized approach for making the finance function futureready. Each round table started with a review of the impact matrix, and the detailed matching results were also available to the participants. The participants broadly agreed with the matching results, with a small number of adjustments but no major changes to the impact matrix. In general, the participants were quite satisfied with having such a matrix available to them, as expressed by comments including: "As an organization and finance function, you are working on all these topics, consciously or unconsciously. You do it as part of everyday work, ad hoc. Thanks to this impact matrix, it is now structured on paper. By looking at it in a structured way, these topics become even more conscious and easier to focus on for us."

Another participant stated: "The discussion gives the possibility to identify the main topics of the organization and what each one of us can contribute to these in the next three to six months. Because you discuss the impact matrix with the employees, this futurizing process is not a management story that is perceived as distant by many people. You bring the future developments into the world of the employees." This remark was added to by another participant: "The impact matrix spells out: the future is the future, this is going to happen, nothing will stay the same. Think of removing routine work from controllers and depositing it in a shared service, in order to fight the increasing skills mismatches and people shortages. The message to employees is then: come up with a list of improvement opportunities and help make our finance function future-ready. This also increases the pride among the finance professionals, as they can state: things will change in the future but we are already working on

International Journal of Management and Applied Research, 2021, Vol. 8, No. 2 
this to prepare ourselves for that future; we therefore continue to provide added value to the organization and even increase it; look what a good, proactive department we are!"

The first round table yielded a first draft of the process for making the finance function futureready, a process which was named 'Futurize the finance function.' During the second round table, this process was refined and optimized until the process depicted in Figure 1 was arrived at.

Figure 1: Schematic depiction of the future-readiness process of the finance function

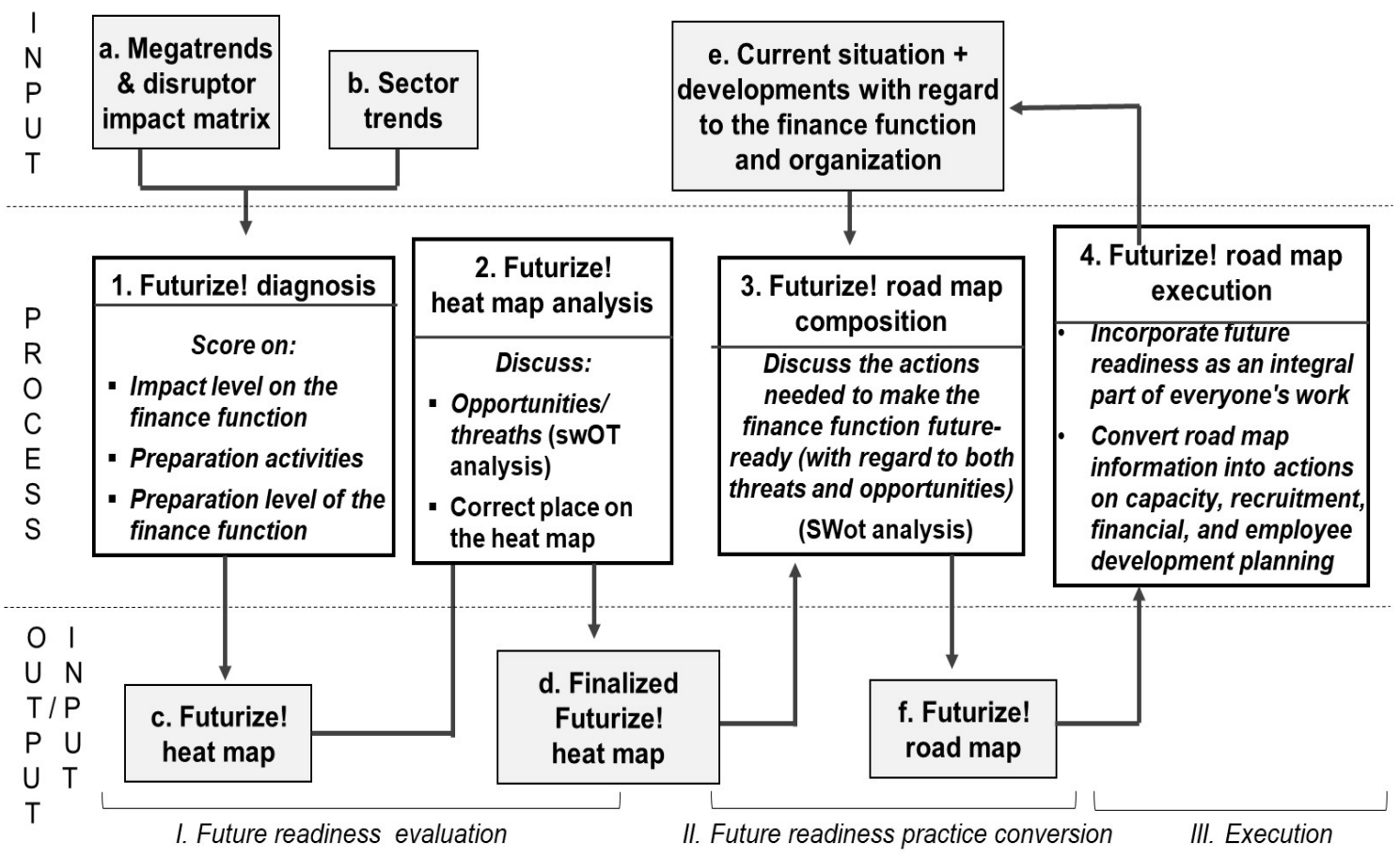

There are three stages and three process levels in the 'Futurize the finance function' process. The process starts with the future-readiness evaluation stage, followed by converting the evaluation results into practical improvement actions, which are put into practice during the execution stage. Each stage has an input and an output that feeds into the next stage; in between is the process that takes place in the stage itself. In the 'future readiness evaluation' stage, based on the impact matrix (Box a in Figure 1) and sector trends (Box b) - which have to be considered separately because the impact matrix looks at worldwide megatrends and disruptors, not at specific sector developments-selected people in the organization (often management team members supplemented by specialists and, for instance, representatives of the work council) score each megatrend and disruptor on: their estimated impact on the organization; the degree in which the organization is preparing itself for each megatrend and disruptor; and how prepared the organization actually is for dealing with each megatrend and disruptor (Box 1 in Figure 1). Based on the summarized scores of the participants, a draft Futurize! heat map is constructed (Box c).

A heat map is generally a two-dimensional array that lists risks on an ordinate based on the impact of the risk, and an abscissa based on the risk probability (Aven, 2017; Bell and Watt, 2013; Duijm, 2015). Thus, a heat map can be used to prioritize risks. We replace 'risk probability' with 'estimated preparedness' so that the heat map depicts the urgency with 
which the organization must prepare itself for a megatrend or disruptor (low impact and low/high preparedness = low urgency; high impact and high preparedness = low urgency; high impact and low preparedness $=$ high urgency).

The draft heat map forms the input for a discussion by a larger group of representatives of the organization (Box 2). During this discussion, each megatrend and disruptor is evaluated on its impact, which can be either positive or negative ('opportunity' or 'threat' in a SWOT analysis, respectively, and degree of preparedness, until the participants agree on the correct place of the megatrend/disruptor in the final Futurize heat map (Box d). This heat map gives priority to the megatrends/disruptor which must be tackled most urgently by the organization.

In stage 2, 'future readiness practice conversion', the finalized heat map forms the basis for a road map, which is constructed by the finance function (Box 3 ) and lists the actions needed to make the finance function future-ready (in regard to defending itself against threats or taking advantage of the opportunities) (Box $\mathrm{f}$ ). In the preparation of the road map, the finance function takes into account the current status of the organization and the finance function itself, in regard to, for instance, the resources, budget, and time available for executing the actions (Box e), so that the resulting road map will be a realistic one.

Finally, in stage 3 'execution', the road map is implemented by incorporating the Futurize actions into the daily practice of the finance function, on the basis of realistic targets in time and effort, set based on capacity, recruitment, financial and employee development plans (Box 4). These plans are looped back into the overview of the current situation of the organization and the finance function (Box e) so that at any time the road map can be updated based on current circumstances and events.

\section{Conclusion, Limitations, and Future Research}

In this paper we attempted to find an empirical answer to the research question: How should a finance function deal with megatrends and disruptors in such a way that it can secure its sustainable performance? Based on a previous study of megatrends and disruptors and their impacts on organizations and using a framework for creating high-performing finance functions, we determined the impacts of the megatrends and disruptors on finance functions. The impact matrix was evaluated by two groups of finance experts, which resulted in an approved impact matrix and in the development of a process - called the Futurize! Diagnosis by which the finance function can make itself future-ready. The results of our research thus add to the literature on finance functions and close the gap in the existing academic literature regarding future-proofing the finance function. The results also provide finance professionals with a practical way to address the megatrends and disruptors coming towards them.

There are several limitations to our study. First, we used the thirteen megatrends and one disruptor from earlier research. It is possible that since that previous study, other megatrends and disruptors have emerged that in the current study should have been taken into account. Future research should check whether changes or additions to the megatrends and disruptors in the literature have taken place. Another limitation may come from the HPFF framework that was chosen as the analysis model to identify opportunities and threats for finance functions. It is possible that other frameworks would have led to different findings and conclusions. We therefore hope that future researchers might replicate our study using different analysis models, and compare their findings with ours. Although we had a 
respectable number of finance experts participating in the round tables, a larger number could have given additional insights, so future research should endeavor to enlist more experts in the discussion. Yet another limitation is that we have not tested the future-readiness process of the finance function for its effectiveness in actual implementation by organizations; we plan to do this in future research. In that research, we will also consider the application of the detailed results of the impact matrix.

\section{References}

1. Aven, T. (2017), "Improving risk characterisations in practical situations by highlighting knowledge aspects, with applications to risk matrices", Reliability Engineering and System Safety, Vol. 167, pp.42-48. https://doi.org/10.1016/j.ress.2017.05.006

2. Ball, D.J. and Watt, J. (2013), "Further thoughts on the utility of risk matrices", Risk Analysis, Vol. 33, No. 11, pp.2068-2078. https://doi.org/10.1111/risa.12057

3. Cambridge Dictionary (2020), Disruptor, Cambridge University Press [Online]. Available from: https://dictionary.cambridge.org/dictionary/english/disruptor?q=disruptors [Accessed on 3 March 2021].

4. Chief Financial Officer (CFO) Research (2014), Building High-Performing Finance Functions, Boston, CA: CFO Publishing LLC.

5. Crabtree, B.F. and Miller, W.L. (1992), Doing Qualitative Research, Newbury Park, CA: Sage Publications.

6. de Waal, A. and Linthorst, J. (2020), "Future-proofing the high-performance organization", Sustainability, Vol. 12, No. 20, paper 8507. https://doi.org/10.3390/su12208507

7. de Waal, A., Bilstra, E. and De Roeck, P. (2019), "Identifying the characteristics of a high-performance finance function", Journal of Advances in Management Research, Vol. 16, No. 3, pp.352-377. https://doi.org/10.1108/JAMR-08-2018-0066

8. Duijm, N.J. (2015), "Recommendations on the use and design of risk matrices", Safety Science, Vol. 76, pp.21-31. https://doi.org/10.1016/j.ssci.2015.02.014

9. Farrar, M. (2019), Re-inventing Finance for a Digital World, the Future of Finance, Chartered Global Management Accountant.

10. Gupta, U.G. and Clarke, R.E. (1996), "Theory and application of the Delphi technique: a bibliography (1975-1994)", Technological Forecasting and Social Change, Vol. 53, No. 2, pp.185-211. https://doi.org/10.1016/S0040-1625(96)00094-7

11. Gutierrez, O. (1989), "Experimental techniques for information requirement analysis", Information and Management, Vol. 16, pp.31-43.

12. Haq, Z., Hafeez, A., Zafar, S. and Ghaffar, A. (2017), "Dynamics of evidence-informed health policy making in Pakistan”, Health Policy \& Planning, Vol. 32, No. 10, pp.14491456. https://doi.org/10.1093/heapol/czx128

13. Hill, G.W. (1982), "Group versus individual performance: are $\mathrm{N}+1$ heads better than one?", Psychological Bulletin, Vol. 91, No. 3, pp.517-539. https://doi.org/10.1037/00332909.91.3.517

International Journal of Management and Applied Research, 2021, Vol. 8, No. 2 
14. Hoe, S.L. (2009), "Transforming finance for the future", Journal of Organisational Transformation and Social Change, Vol. 6, No. 1, pp.65-77. https://doi.org/10.1386/jots.6.1.65_1

15. Kniffin, K.M., Narayanan, J., Anseel, A.J., Ashford, S.P., Bakker, A. B., Bamberger, P., Bapuji, H., Bhave, D. P., Choi, V. K., Creary, S. J., Demerouti, E., Flynn, F. J., Gelfand, M. J., Greer, L. L., Johns, G., Kesebir, S., Klein, P. G., Lee, S. Y., Ozcelik, H., Petriglieri, J. L., Rothbard, N. P., Rudolph, C. W., Shaw, J. D., Sirola, N., Wanberg, C. R., Whillans, A., Wilmot, M. P., Van Vugt, M. (2020), "COVID-19 and the workplace: Implications, issues, and insights for future research and action", American Psychologist, Vol. 76, No. 1, pp. 63-77. https://doi.org/10.1037/amp0000716

16. Koonin, L.M. (2020), "Novel coronavirus disease (COVID-19) outbreak: now is the time to refresh pandemic plans", Journal of Business Continuity \& Emergency Planning, Vol. 13, No. 4, pp.298-312.

17. Linthorst, J. and de Waal, A. (2020), "Disruptive forces and their postulated impact on organizations", Sustainability, Vol. 12, No. 20, paper 8740. https://doi.org/10.3390/su12208740

18. Merriam, S.B. (1998), Qualitative Research and Case Study Applications in Education, San Francisco, CA.: Jossey-Bass Publications.

19. Naisbitt, J. and Aburdene, P. (1990), Megatrends 2000: Ten New Directions for the 1990’s, New York: HarperCollins Publishers.

20. Nielsen, H. and Kristensen, T.B. (2020), "Impact of lean operations on the roles of finance functions and their application of lean", European Business Review, Vol. 32, No. 4, pp.731-763. https://doi.org/10.1108/EBR-10-2019-0277

21. O'Connor, J., Schneider, L. and Willman, T. (2014), The World-Class Performance Advantage: How Leading Finance Organizations Outperform their Peers, Miami, FL: The Hackett Group,.

22. O'Connor, J., Schneider, L. and Willman, T. (2015), The CFO Agenda: Key Issues for Finance in 2015, Miami, FL: The Hackett Group.

23. OECD (2007), "Summary of the discussion", OECD Journal of Competition Law \& Policy, Vol. 8, No. 3, pp.222-246. https://doi.org/10.1787/clp-v8-art8-en

24. Paliokaitè, A., Pačèsa, N. and Sarpong, D. (2014), "Conceptualizing strategic foresight: an integrated framework", Strategic Change, Vol. 23, No. 3-4, pp.161-169. https://doi.org/10.1002/jsc.1968

25. PricewaterhouseCoopers (PwC) (2014), Finance matters, finance function of the future, [Online] Available from: https://www.pwc.nl/nl/assets/documents/pwc-financematters.pdf [Accessed on 5 January 2021].

26. Ribera, J. (2020), "Business and Management Lessons Learned from COVID-19", in: Liebowitz, J. (Ed.), The Business of Pandemics: The COVID-19 Story, Boca Raton: Auerbach Publications. https://doi.org/10.1201/9781003094937

27. Saludadez, J.A. and Garcia, P.G. (2001), "Seeing our quantitative counterparts: construction of qualitative research in a roundtable discussion", Forum: Qualitative Social Research, Vol. 2, No. 1, pp.193-203. https://doi.org/10.17169/fqs-2.1.973

International Journal of Management and Applied Research, 2021, Vol. 8, No. 2 
28. Singer, J.N., Shaw, S., Hoeber, L., Walker, N., Agyemang, K.J.A. and Rich, K. (2019), "Critical conversations about qualitative research in sport management", Journal of Sport Management, Vol. 33, No. 1, pp.50-63. https://doi.org/10.1123/jsm.2018-0085

29. Smith, S., Winchester, D., Bunker, D. and Jamieson, R. (2010), "Circuits of power: a study of mandated compliance to an information systems security de jure standard in a government organization", MIS Quarterly, Vol. 34, No. 3, pp.463-486.

30. Wolf, S., Weißenberger, B.E., Wehner, M.C. and Kabst, E. (2015), "Controllers as business partners in managerial decision-making: attitude, subjective norm, and internal improvements", Journal of Accounting \& Organizational Change, Vol. 11, No. 1, pp.2446. https://doi.org/10.1108/JAOC-10-2012-0100

31. Zoni, L. and Merchant, K.A. (2007), "Controller involvement in management: an empirical study in large Italian corporations", Journal of Accounting \& Organizational Change, Vol. 3, No. 1, pp.29-43. https://doi.org/10.1108/18325910710732849 